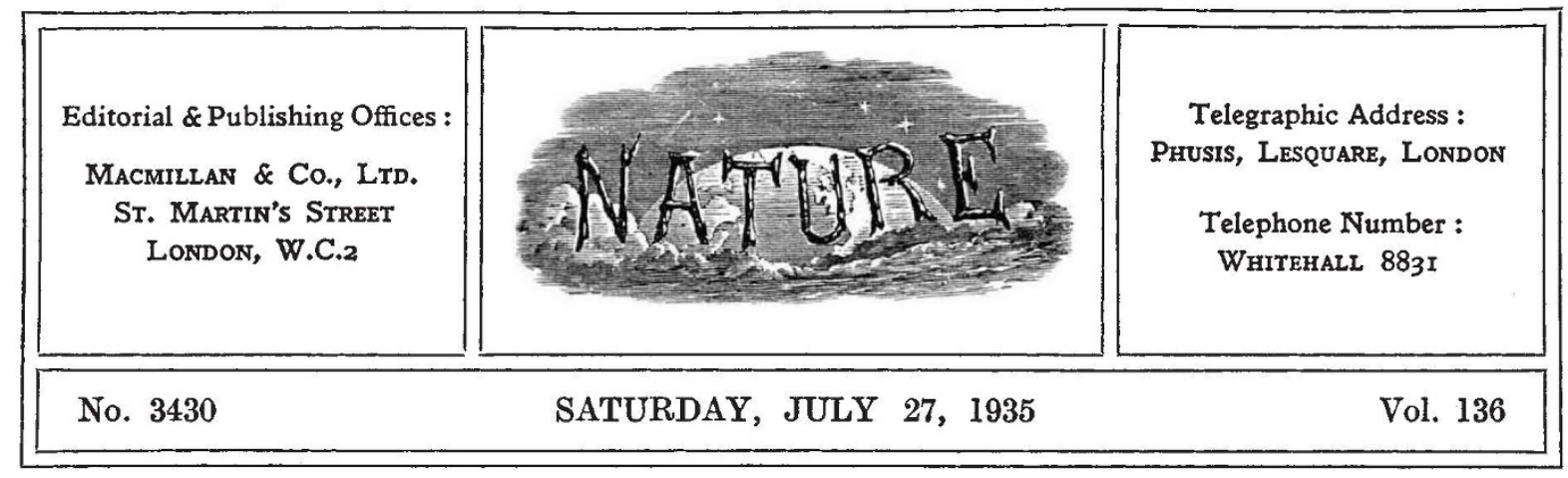

\title{
Culture and Policy in Basutoland
}

$A^{M O N G}$ the simpler peoples, we are told by A members of the functional school of anthropological thought, no element of culture can be studied apart from its social context. This axiom, writ large, is the theme of the report of the Commission* appointed by the Secretary of State for Dominion Affairs to inquire into the financial and economic position of Basutoland, of which Sir Alan Pim was chairman and Mr. S. Milligan, representative in South Africa of the Cotton Growing Corporation, and Mr. H. Lesley Smith were the members (see NATURE, June 22, p. 1028). Throughout the report, it is evident that the members of the Commission were deeply impressed by the interlock of social and cultural conditions with those of the financial and economic position, present and future, and by the. complete dependence of the political and social advancement of the community as a whole on a harmonious adjustment between such of them as will tend to conflict when faced with change; and in effect, as their final analysis of the situation, the conclusion is stressed that failure to guide the cultural and ethnic characteristics of the Basuto nation into a path which will open the way for a progressive policy, will lead to complete political and cultural breakdown. Basuto society, as at present organised, according to the Commission, is unable to adjust itself to meet the economic strain.

It is a remarkable symptom of the sensitiveness of the modern world as a whole to the influences affecting any one of its parts in any serious degree, that the economic depression which has crippled the more advanced civilisations has not passed by the backward peoples. Over-production

* Financial and Economic Position of Basutoland : Report of the Commission appointed by the Secretary of State for Dominion Affairs, January, 1935. Pp. viii +225. (London: H.M. Stationery Office, 1935.) 38 . $6 d$. net. and unemployment find their counterpart in the relatively more primitive communities, though not always recognisable as such when translated into terms of non-European culture. Among the pastoral and semi-pastoral Bantu peoples of Africa, especially in the south of the continent, overstocking of the pastoral lands, made possible by the extra-territorial employment of labour, takes the place of the over-production and maldistribution of commodities, while the social consequences of unemployment find their parallel in the effects of the shortage of cultivable land, which bars an appreciable number of the members of the tribe from full participation in the organisation of the community, owing to the lack of the 'lands', which a man is eligible to hold for cultiva. tion on marriage as an essential concomitant of family life.

It is to be noted, however, that the depression is not entirely responsible for this state of affairs. Rather, it has aggravated a situation which has grown out of certain characteristics of Bantu culture. These tend to give rise to difficulties, which become acute when brought into touch with modern economic conditions, especially the employment of native labour at a remuneration, and the introduction of an effective system of administration, eliminating such checks on over-population and its consequences as warfare and freedom of movement, which mitigated these evils under the old tribal regime.

In all three of the South African Protectorates, the financial and economic outlook is grave. Basutoland, though by no means in such serious straits as Bechuanaland, has almost entirely dissipated its financial reserves, accumulated in a period of prosperity, through the measures of 
relief which have been necessitated by the fall in the value of its exports of wool, which now stands at less than a third of what it was a few years ago and will fall still lower, and the effects of a two years' drought. The seriousness of the crisis may be gauged by the fact that not only the holdings of sheep, but also the stocks of cattle, the most essential possession of Bantu culture, have shrunk to one half in this time of distress. This catastrophe, however, is by no means an unmitigated misfortune. It has, to some extent, though not entirely, automatically relieved the over-stocking of the pasture land. A further relief has come with the rains. But neither the rapid recovery of vegetation, notwithstanding the onslaughts of the locust, nor the nearer adjustment of stock to the carrying capacity of the land-possibly temporary and pending the return to individual prosperity-will afford any substantial help towards the solution of the problems of Basutoland's future economic and financial stability. The causes are more deeply rooted.

Basutoland, which is one of the most pleasant, is also in part one of the most thickly populated areas of South Africa. Occupation is, or was, confined almost exclusively to the lowlands, which in the semi-pastoral, semi-agricultural economy of the Basuto are mostly under cultivation. The hill regions are devoted to seasonal grazing. In recent years, however, scattered villages have begun to appear in the uplands, though owing to the consequent reduction of pasture and other evils, these settlements have been forbidden by the Paramount Chief. This veto to a certain extent has been ignored.

In a little less than forty years, the population of Basutoland has more than doubled. It is now estimated to stand at 570,000 . This is not entirely a natural increase. There has been a considerable immigration of Tembus from the Union, their accession increasing the prestige of the chief. The Basuto, like a number of other Bantu peoples of South Africa, such as the Matabele, came into independent existence during the troubled times of the beginning of the nineteenth century. Unlike others, however, they were not a single tribe or a homogeneous group, but a congeries of unrelated groups, who gradually came to form a confederation under the Bakwena, or "People of the Crocodile", and were moulded into a nation under the prolonged rule of Moshesh (reg. 1815-70). Further, throughout their relations with the whites, they were never subdued, but maintained their in- dependence. These are crucial facts in determining the character of present problems and the method to be adopted in the approach to their solution. The dominance of the Bakwena has by now, for the most part, eliminated the original tribal chiefs, and through the system of 'planting out' the younger sons of chiefs as subordinate chiefs, each with a court, a chief's holding of land, and a revenue dependent on fines, has produced a complicated and ever-increasing system of chiefs and jurisdictions of which the possibilities of abuse are obvious, especially as these petty chiefs have acquired a taste for the luxuries of modern civilisation, such as the motor-car, which their legitimate financial resources scarcely permit them to gratify. One serious defect of the system is that it has gravely affected the security of landtenure, as the land, which in theory belongs to the Paramount Chief as trustee for his people and is at his disposal, may be required at any time for the settlement of a new chief.

As a result of their past history, both chiefs and people are acutely conscious of their independence, and although the people are by no means satisfied under the multiplicity of chiefs and fully alive to the defects of character and weaknesses of individual chiefs, they are intensely loyal to the chieftainship as an institution. Any change of custom, however advantageous, would meet with serious resistance, if it were held to be an encroachment on their independence or the prerogative of the chief.

Such interference is clearly foreshadowed in the far-reaching recommendations of the Commission. Although administration as such does not come within its province, the members have accepted the position that custom, social organisation and financial and economic stability are so closely interrelated, that if the reforms which they consider essential are to be carried out with financial assistance from outside, administrative changes and cultural modifications are essential which will necessitate a drastic change in what has hitherto been a policy of non-interference in internal affairs-of protection without control.

The three elements in Basuto culture, which thus insistently demand attention-the position and authority of the chief, the holdings of stock and the system of land tenure-are everywhere among the Bantu crucial problems of administration. In Basutoland these elements in culture, operating without check in certain directions, have reinforced the natural tendency of the 
country to surface erosion and thereby added to the difficulty of the social and economic situation. This applies more particularly to overstocking and the consequent overgrazing, and to the breaking up of the upland pastures for cultivation, owing to the shortage of 'lands' in the lowlands. The removal of the natural protection of the surface soil by these agencies destroys fertility and leaves the land a prey to weeds. The evil is progressive ; and the elements in culture which have aggravated the trouble are, as indicated, equally an obstruction in the way of remedial measures. Even if the country had the requisite financial resources, the essential reorganisation for reform of practice is beyond the competence of existing authority. The policy of non-interference is plainly no longer in the interest of the Basuto nation or its future as an integral part of South Africa.

of possible alternatives, the Commission favours the introduction of a real and effective system of 'indirect rule', operating through a reformed chieftainship and based upon the intense loyalty of the people to the institution of the chieftainship.
Only thus, the Commission holds, will it be possible to put into operation measures to check progressive deterioration in the economy of the Basuto and set them on the way to a return to the prosperity which they enjoyed up to a few years ago.

The report of the Commission is neither concerned with nor mentions the question of the future of the Protectorate in its specific relation to the Union of South Africa. On this aspect the recently published White Paper (see Nature, July 20, p. 96) has cleared the air by its insistence on the necessity for a breathing space to allow a policy formulated in the interest of the native to come to fruition. Not only does it reaffirm the obligation of the British Government to consult the native population of Basutoland, as well as of the other Protectorates, before steps are taken to effect their transfer to the Union, but also it invites the co-operation of the Union Government in the next few years in a policy which will convince the native population of "a real and generous desire to improve conditions in the Territories".

\section{Minerals and International Security}

The Mineral Sanction as an Aid to International Security

By Sir Thomas H. Holland. Pp. 96. (Edinburgh and London: Oliver and Boyd, 1935.) 2s. net.

THIS interesting little book appears at an 1 opportune moment. Books on international affairs are indeed numerous, and we have plenty of books on minerals ; but minerals in relation to international security, and a thesis that the warlike disposition of an aggressor nation can be and should be held in check by a sanction based on mineral supplies, is a fairly new theme, a consideration of which serves to show how vitally necessary for war purposes, as well as for industrial purposes, mineral supplies really are. So long ago as 1929, Sir Thomas Holland discussed the suggestion in his presidential address at the meeting of the British Association in South Africa.

Minerals indeed, as the very stuff of the earth, are fundamental substances. Man has long used the metals, but not until the industrial era did he begin to develop their specialised uses for the purposes that fill so important a place in modern industry. The utilisation of iron and steel at the present day involves the use of a number of alloy metals, including manganese, chromium, nickel, cobalt, tungsten, molybdenum and vanadium, without access to which the metallurgy of iron as we now know it would not be practicable. Iron and the ferro-alloy metals are essential as munitions of war. So are aluminium, antimony, copper, lead, quicksilver, tin and zinc, and some of the more important non-metals, including fluorspar, graphite, magnesite, mica, petroleum and sulphur. All these minerals are briefly and simply accounted for in Part 3 of this book, in which a short account is given of their importance as war materials.

In Part 2 an account is given of the mineral position in each of the important industrial countries, including the United States, Great Britain, France, Germany, Italy, Japan and Russia, showing with which of the important minerals and metals these countries are well supplied and those in which they are deficient.

The British Empire is well equipped with minerals as a whole, but constituent countries considered separately are seriously deficient. The United States, considered as a geographical unit, is better provided for than any other country as regards war minerals. France, Germany, Italy and Japan each has a long list of war minerals 